\title{
Synthesis, Characterization, Molecular Docking and Enzyme Inhibition Studies of Some Novel Enaminone Derivatives and Their Complexes with $\mathrm{Cu}(\mathrm{II}), \mathrm{Cd}(\mathrm{II})$ and $\mathrm{Co}(\mathrm{II})$ lons
}

\author{
RAHILA HUMA ${ }^{1,2}$, TARIQ MAHMUD², LIVIU MITU³, MUHAMMAD ASHRAF ${ }^{4}$, AMBAR IQBAL $^{4}$, KIRAN IFTIKHAR $^{5}$, ANUM HAYAT ${ }^{1}$ \\ 1Kinnaird College for Women, 93-J ail Road Lahore-54000, Pakistan \\ Institute of Chemistry, University of the Punjab, Lahore-54590, Pakistan \\ 3University of Pitesti, Department of Chemistry, 1 Targu din Vale Str., 110040, Pitesti, Romania \\ ${ }^{4}$ Department of Chemistry, The Islamia University of Bahawalpur, Bahawalpur-63100, Pakistan \\ ${ }^{5}$ Department of Chemistry, University of Gujrat (UOG), Gujrat, Pakistan
}

\begin{abstract}
Two new enaminone ligands, 3-chloro-4-\{(4-chlorophenyl)amino\}pent-3-en-2-one (Ac-PCA), 4(benzylamino)-3-chloropent-3-en-2-one (Ac-BA) and their metal complexes with transition metal ions [CU(II), Cd(II) and Co(II)] were prepared and subsequently characterized by FTIR, ICP-AES, UV-Vis, TGA, ${ }^{1} H$ NMR, ${ }^{13} \mathrm{C} N M R$ and FAB-MS. These newly synthesized compounds were further investigated for antiacetylcholinesterase (AChE) and anti-urease activities. The (Ac-BA)CU(II) complex exhibited good anti$A C h E$ while $(A C-B A){ }_{2} C O(I I)$ complex was potent againstanti-urease activities. Other ligands and complexes showed poor to no enzyme inhibitory activities. The synthesized compounds were docked inside acetylcholinesterase enzymes to determine their putative binding mode.
\end{abstract} Keywords: Antiureas activity, enaminone, metal complexes, acetylcholinesterase inhibition
studies

One of the main goals for chemists and pharmacologists is the synthesis of novel biologicallyactive compounds that can act as better drugs to fight against diseases. Coordination chemistry, therefore, has developed very rapidly since many ligands of low biological activity became more active when they were converted to metal complexes and some drugs show increased activity when reacted with metal ions to form metal complexes [1, 2]. The literature search has shown several publications on the chemistry of enaminones and their derivatives, their physicochemical properties and biological activities [3-5]. On the other hand, enaminones have been extensively used as key intermediates in organic synthesis and the chemistry of these compounds has been reviewed [6]. The presences of carbonyl group connected by carbon=carbon double bond and an amino group or $\mathrm{N}$ substituted amines in enaminones make them bidentate ligands [7]. Enaminones have become more important because they can be used as good chelating ligands for transition metals and the anions generated from them give isoelectronic replacements to cyclopentadienyl-based anions. Therefore, enaminone metal complexes can act as alternative catalysts for olefin polymerization [8, 9]. Complexes of different metal ions with enaminones have also been reported [10-12]. The structure and areas of practical application of fluoroalkyl containing enaminoketone chelates with $d$-metals have been reviewed [13].

Such complexes have wide applications in differentareas of industry and engineering $[14,15]$.

In view of these facts, the present work involves the synthesis of enaminones and their complexes with $\mathrm{Cu}(I I)$, $\mathrm{Co}(\mathrm{II})$ and $\mathrm{Cd}(\mathrm{II})$ ions. The newly synthesized enaminones and their metal complexes were characterized by FT-IR, NMR, Mass spectrometry, TGA and elemental analysis. All the synthesized compounds were screened for urease and acetylcholinesterase inhibition activity. The enzyme inhibitory action was explained by the docking studies and the binding mode of best active compound was also predicted.

\section{Experimental part \\ Materials}

The starting materials and solvents used for the synthesis of ligands and complexes were purchased from commercial dealers and were used without purification. Metal(II) chlorides and acetates were used without any refining because of their analytical ranking.

\section{Physical measurements}

The IR spectrum was recorded on Agilent Technologies FT-IR instrument (in range of $4000-400 \mathrm{~cm}^{-1}$ ). The ${ }^{1} \mathrm{H}-\mathrm{NMR}$ ( $300 \mathrm{MHz}$ ) spectrum was recorded on a Bruker Ascend NMR spectrometer using TMS as an internal standard. The (FAB) mass spectrum was recorded on a JEOL JMS-600H Mass Spectrometer.

\section{Synthesis of Ligands}

Ligands (AC-PCA and Ac-BA) were synthesized in accordance with the reported method [16]. 3-chloro-2,4pentanedione $(0.02 \mathrm{~mol}, 2.25 \mathrm{~mL}), p$-chloroaniline $(0.02$ $\mathrm{mol}, 2.5 \mathrm{~g})$ / benzylamine $(0.02 \mathrm{~mol}, 2.18 \mathrm{~mL})$, and toluene $(150 \mathrm{~mL})$ were refluxed on a heating mantle for $12 \mathrm{~h}$. DeanStark apparatus is used to remove the water produced in reaction mixture. The reaction was monitored by TLC (hexane : ethyl acetate; 8:1) and the spots were detected by ultraviolet light. Solvent was removed under reduced pressure and the viscous oily liquid was dissolved in chloroform and stirred with concentrated aqueous sodium bicarbonate. The organic layer was separated, dried over anhydrous sodium sulphate and solvent evaporated. Pure product obtained as shiny crystals were found to be stable in air and light (Scheme 1 and 2).

\section{(Ac-PCA)}

Molecular formula: $\mathrm{C}_{1} \mathrm{H}_{11} \mathrm{Cl}$ NO; Light yellow solid; Yield: 71 \%; m.p.: $77^{\circ} \mathrm{C}$; Molècular weight: $244.12 \mathrm{~g} / \mathrm{mol}$; 
IR ( $\left.\mathrm{cm}^{-1}\right): 3125(\mathrm{NH}), 1655(\mathrm{C}=0), 1548(\mathrm{C}=\mathrm{C}) ;{ }^{1} \mathrm{H}$ NMR ( $\left.300 \mathrm{MHz}, \mathrm{CDCl}_{3}, \delta \mathrm{ppm}\right): 12.71(\mathrm{~s}, 1 \mathrm{H},-\mathrm{NH}), 7.35(\mathrm{~d}, 2 \mathrm{H}$, -Ar-H), $7.03(\mathrm{~d}, 2 \mathrm{H},-\operatorname{Ar}-\mathrm{H}), 2.38(\mathrm{~s}, 3 \mathrm{H}), 2.18(\mathrm{~s}, 3 \mathrm{H}) ;{ }^{13} \mathrm{C}$ NMR $\left(75 \mathrm{MHz}, \mathrm{CDCl}_{3}, \delta \mathrm{ppm}\right): 194.97,157.74,137.05$, $131.73,129.37,126.51,104.93,28.67,18.15$; FAB-MS: $m /$ $\mathrm{Z}=244.1[\mathrm{M}+\mathrm{H}]^{+}$; Anal.Calc., (\%) for

$\mathrm{C}_{1} \mathrm{H}_{1} \mathrm{Cl} \mathrm{NO}: \mathrm{C}, 54.12 ; \mathrm{H}, 4.54 ; \mathrm{N}, 5.74$; Found: C, 52.58; $\mathrm{H}, 3.92 ; \mathrm{N}, 5.82$.

\section{(Ac-BA)}

Molecular formula: $\mathrm{C}_{12} \mathrm{H}_{14} \mathrm{CINO}$; Pale yellow solid; Yield: $60 \%$; m.p.: $70^{\circ} \mathrm{C}$; Molecủlar weight: $223.70 \mathrm{~g} / \mathrm{mol}$; IR (cm 1): $3132(\mathrm{NH}), 1593(\mathrm{C}=0), 1561(\mathrm{C}=\mathrm{C})$; ${ }^{1} \mathrm{H}$ NMR (300 $\left.\mathrm{MHz}, \mathrm{CDCl}_{3}, \delta \mathrm{ppm}\right): 11.68(\mathrm{~s}, 1 \mathrm{H},-\mathrm{NH}), 7.40-7.25(\mathrm{~m}, 5 \mathrm{H}$, $-\mathrm{Ar}-\mathrm{H}), 4.52\left(\mathrm{~d}, 2 \mathrm{H},-\mathrm{CH}_{2}-\right), 2.32(\mathrm{~s}, 3 \mathrm{H}), 2.17(\mathrm{~s}, 3 \mathrm{H}) ;{ }^{13} \mathrm{C}$ NMR ( $75 \mathrm{MHz}, \mathrm{CDCl}_{3}, \delta \mathrm{ppm}$ ): 193.60, 161.19, 137.50, 128.93,

$127.66,126.77,102.61,47.69,28.66,16.68 ;$ FAB-MS: $\mathrm{m} /$ $z=224.1[\mathrm{M}+\mathrm{H}]^{+}$; Anal.Calc., $\%$ for $\mathrm{C}_{1} \mathrm{H}_{1}$ CINO: C, 64.43; $\mathrm{H}, 6.31 ; \mathrm{N}, 6.26$; Found: $\mathrm{C}, 65.35 ; \mathrm{H}, 5.24 ; \mathrm{N}, 5.18$.

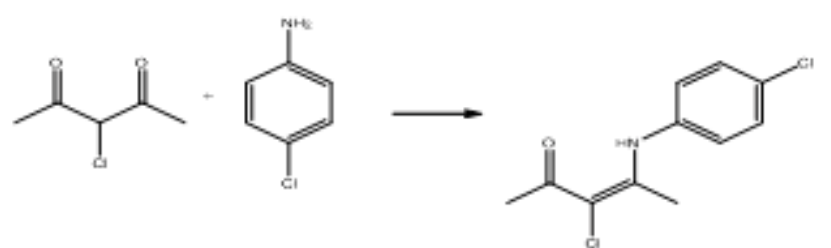

Scheme 1. Synthesis of 3-chloro-4-\{(4-chlorophenyl)amino\}pent-3en-2-one (AC-PCA)

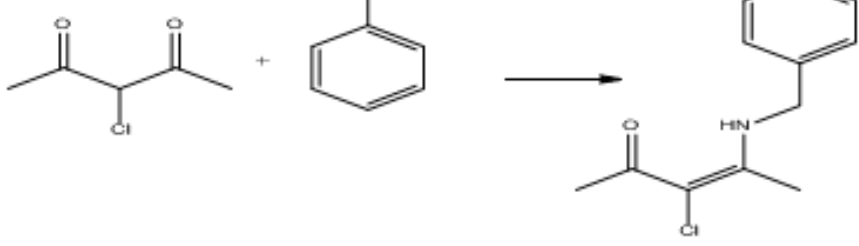

Scheme 2. Synthesis of 4-(benzylamino)-3-chloropent-3-en-2-one (Ac-BA)

Synthesis of metal complexes

$\mathrm{Cu}$ (II) complex of 3-chloro-4-\{(4-chlorophenyl)amino $\}$ pent-3-en-2-one (AC-PCA)Cu(II)

A solution of (AC-PCA) $(0.01 \mathrm{~mol})$ in $10 \mathrm{~mL} \mathrm{DCM}$ (Dichloromethane) was added drop wise with continuous stirring to a $10 \mathrm{~mL}$ of filtered ethanolic solution of the $\mathrm{CuCl}$ $(0.01 \mathrm{~mol})$ and refluxed for $5 \mathrm{~h}$. The complex was obtained by filtration and evaporated slowly at room temperature. The synthesis of coordination compound had good yield. Molecular formula: [ $\mathrm{C}_{1} \mathrm{H}_{1} \mathrm{Cl}$ CuNO]; Green solid; Yield: 43 $\%$; m.p.: decomposed above $280^{\circ} \mathrm{C}$; Molecular weight: $378.57 \mathrm{~g} / \mathrm{mol} ; \mathrm{IR}\left(\mathrm{cm}^{-1}\right): 3337(\mathrm{NH}), 1640(\mathrm{C}=0$ conjugated), 1562 ( $C=C$ stretching), 443 (Cu-N stretching), 547 (Cu-O stretching); Anal.Calc., (\%) for $\mathrm{C}_{11} \mathrm{H}_{11} \mathrm{Cl}$ CuNO: C, 34.90; H, 2.93; N, 3.70; Found: C, 34.41; H, 2.65; N, 3.50; (\%) Cu for $\left[\mathrm{MLCl}_{2}\right.$ ]: theoretical/experimental (16.79/17.48).

$$
\mathrm{Ac}-\mathrm{PCA}+\mathrm{CuCl}_{2} \rightarrow\left[\mathrm{Cu}(\mathrm{Ac}-\mathrm{PCA}) \mathrm{Cl}_{2}\right]
$$

$\mathrm{Cd}$ (II) complex of 3-chloro-4-\{(4-chlorophenyl) amino $\}$ pent-3-en-2-one (Ac-PCA), Cd(II)

A solution of (AC-PCA) $(0.02 \mathrm{~mol})$ in $10 \mathrm{~mL}$ DCM was added drop wise with continuous stirring to a $10 \mathrm{~mL}$ of filtered ethanolic solution of the $\mathrm{CdCl}_{2}(0.01 \mathrm{~mol})$ and refluxed for $2 \mathrm{~h}$. The complex was obtained by filtration and evaporated slowly at room temperature. The synthesis of coordination compound had good yield. Molecular formula: [ $\mathrm{C}_{22} \mathrm{H}_{22} \mathrm{Cl}_{6} \mathrm{CdN}_{2} \mathrm{O}_{2}$ ]; Light yellow solid; Yield: 41 \%; m.p.: decomposed at 240-244\% $\mathrm{C}$; Molecular weight: $671.55 \mathrm{~g} / \mathrm{mol}^{\prime}$ IR $\left(\mathrm{cm}^{-1}\right): 3405(\mathrm{NH}), 1645(\mathrm{C}=0$ conjugated), 1541 ( $C=C$ stretching), 454 ( $C d-N$ stretching), 525 (Cd-O stretching); ${ }^{1} \mathrm{H}$ NMR ( $\left.300 \mathrm{MHz}, \mathrm{CDCl}_{3}, \delta \mathrm{ppm}\right)$ : $12.66(\mathrm{~s}, 1 \mathrm{H},-\mathrm{NH}), 7.46(\mathrm{~d}, 2 \mathrm{H},-\mathrm{Ar}-\mathrm{H}), 7.27(\mathrm{~d}, 2 \mathrm{H},-\mathrm{Ar}-\mathrm{H})$, $2.27(\mathrm{~s}, 3 \mathrm{H}), 2.16(\mathrm{~s}, 3 \mathrm{H})$; Anal.Calc., (\%) for $\mathrm{C}_{22} \mathrm{H}_{22} \mathrm{Cl}_{6} \mathrm{CdN}_{2} \mathrm{O}$ : C, 39.35; $\mathrm{H}, 3.30$; N, 4.17; Found: $\mathrm{C}$, 38.10; $\mathrm{H}^{22} 2.95 ; \mathrm{N}, 4.05 ;(\%) \mathrm{Cd}$ for $\left[\mathrm{ML}_{2} \mathrm{Cl}_{2}\right]$ : theoretical/ experimental (16.74/14.56).

$$
2 \mathrm{Ac}-\mathrm{PCA}+\mathrm{CdCl}_{2} \rightarrow\left[\mathrm{Cd}(\mathrm{Ac}-\mathrm{PCA})_{2} \mathrm{Cl}_{2}\right]
$$

$\mathrm{Cu}$ (II) complex of 4-(benzylamino)-3-chloropent-3-en-2one (Ac-BA) Cu(II)

A solution of (Ac-BA) $(0.01 \mathrm{~mol})$ in $10 \mathrm{~mL}$ DCM was added drop wise with continuous stirring to a $10 \mathrm{~mL}$ of filtered ethanol solution of the Copper acetate monohydrate $(0.01 \mathrm{~mol})$ and refluxed for $4 \mathrm{~h}$. The complex was obtained by filtration and evaporated slowly at room temperature. The synthesis of coordination compound had good yield. Molecular formula: [ $\mathrm{C}_{16} \mathrm{H}_{20} \mathrm{ClCuNO}_{5}$ ]; Light green solid; Yield: 49 \%; m.p.: decomposed above $280^{\circ} \mathrm{C}$; Molecular weight: $405.33 \mathrm{~g} / \mathrm{mol}^{\prime}$ IR $\left(\mathrm{cm}^{-1}\right)$ : $3420(\mathrm{NH}), 1633(\mathrm{C}=0$ conjugated), 1558 ( $C=C$ stretching), 453 ( $C u-N$ stretching), 542 (Cu-O stretching); Anal.Calc., (\%) for $\mathrm{C}_{16} \mathrm{H}_{2} \mathrm{ClCuNO}$ : C, 47.41; H, 4.97; N, 3.46; Found: C, 46.33; H, 3.99; N, 3.30; (\%) $\mathrm{Cu}$ for $\left[\mathrm{ML}\left(\mathrm{CH}_{3} \mathrm{COO}\right)_{2}\right]$ : theoretical/experimental (15.68/14.46).

$$
\mathrm{Ac}-\mathrm{BA}+\mathrm{Cu}\left(\mathrm{CH}_{3} \mathrm{COO}\right)_{2} \rightarrow\left[\mathrm{Cu}(\mathrm{Ac}-\mathrm{BA})\left(\mathrm{CH}_{3} \mathrm{COO}\right)_{2}\right]
$$

Co(II) complex of 4-(benzylamino)-3-chloropent-3-en-2one (Ac-BA) ${ }_{2} \mathrm{Co}$ (II)

A solution of (AC-BA) $(0.02 \mathrm{~mol})$ in $10 \mathrm{~mL}$ DCM was added drop wise with continuous stirring to a $10 \mathrm{~mL}$ of filtered ethanolic solution of the $\mathrm{Co}\left(\mathrm{CH}_{3} \mathrm{COO}\right)_{2} .4 \mathrm{H}_{2} \mathrm{O}(0.01$ $\mathrm{mol}$ ) and refluxed for $6 \mathrm{~h}$. The complex was obtained by filtration and evaporated slowly at room temperature. The synthesis of coordination compound had good yield. Molecular formula: [ $\mathrm{C}_{28} \mathrm{H}_{33} \mathrm{Cl}_{2} \mathrm{CoN}_{2} \mathrm{O}_{6}$; Light pink solid; Yield: 55 \%; m.p.: decomposed above $280^{\circ} \mathrm{C}$; Molecular weight: $624.42 \mathrm{~g} / \mathrm{mol}^{\prime}$ IR $\left(\mathrm{cm}^{-1}\right)$ : $3405(\mathrm{NH}), 1605(\mathrm{C}=0$ conjugated), 1560 ( $C=C$ stretching), 440 ( $\mathrm{Co-N}$ stretching), 545 (Co-0 stretching); Anal.Calc., (\%) for

$\mathrm{C}_{2} \mathrm{H}_{3} \mathrm{Cl}_{2} \mathrm{CON}_{2} \mathrm{O}$ : C, 53.86; $\mathrm{H}, 5.49$; $\mathrm{N}, 4.49$; Found: $\mathrm{C}$, $53.71 ; \mathrm{H}, 4.75 ; \mathrm{N}^{6}, 3.57 ;(\%)$ Co for $\left[\mathrm{ML}_{2}\left(\mathrm{CH}_{3} \mathrm{COO}\right)_{2}\right]$ : theoretical/experimental $(9.44 / 8.05)$.

$$
2 \mathrm{Ac}-\mathrm{BA}+\mathrm{Co}\left(\mathrm{CH}_{3} \mathrm{COO}\right)_{2} \rightarrow\left[\mathrm{Co}(\mathrm{Ac}-\mathrm{BA})_{2}\left(\mathrm{CH}_{3} \mathrm{COO}\right)_{2}\right]
$$

\section{Thermal study (TGA/DTA)}

The metal complexes were exposed to TGA to test their stability and decomposition pattern on heating. Thermal studies were done by using SDT-Q 600 V20.9 Build 20 in an inert atmosphere containing nitrogen gas from ambient to $800^{\circ} \mathrm{C}$.

\section{Biological evaluation}

Acetylcholinesterase assay

Anti-AChE activity was done according to the Ellman method with some changes [17]. $100 \mu \mathrm{L}$ of reaction mixture contained $60 \mu \mathrm{L}$ - $50 \mathrm{mM}$ phosphate buffer, $\mathrm{pH}$ 7.7, $10 \mu \mathrm{L}$ sample $(0.5 \mathrm{mM}$ per well) was added to it, followed by the addition of $10 \mu \mathrm{L}$ ( 0.005 unit per well) electric eel enzyme (Sigma Inc.). The reaction mixture were pre-read at $405 \mathrm{~nm}$ using Synergy HT, BioTek, USA. Then contents were pre-incubated for $10 \mathrm{~min}$ at $37^{\circ} \mathrm{C}$ and reaction was started by the addition of $10 \mu \mathrm{L}$ of $0.5 \mathrm{mM}$ per well 
acetylthiocholine iodide substrate, followed by the adding $10 \mu \mathrm{L} 0.5 \mathrm{mM}$ per well DTNB. Absorbance was measured at $37^{\circ} \mathrm{C}$, after $15 \mathrm{~min}$ of incubation. All experiments were performed in triplicate with their respective controls. For positive control Eserine was used. The \% inhibition was calculated as mentioned below for urease assay.

\section{Urease assay}

In vitro urease inhibition activity was measured by the phenol hypochlorite method [18]. Reaction mixture of 85 $\mu \mathrm{L}$ contained $10 \mu \mathrm{L}$ of phosphate buffer, $p \mathrm{H} 7.0$ in each well in the 96-well plate followed by the addition of $10 \mu \mathrm{L}$ of test solution $(0.25 \mathrm{mM})$ and $25 \mu \mathrm{L}$ of 0.015 units of jack beans urease (Sigma Inc.). At $37^{\circ} \mathrm{C}$, the contents were preincubated for $10 \mathrm{~min}$ and $40 \mu \mathrm{L}$ of $20 \mathrm{mM}$ urea solution was added to each well of plate and incubation continued for further $10 \mathrm{~min}$ and pre-read at $625 \mathrm{~nm}$ using Synergy HT BioTek, USA reader. Phenol hypochlorite reagent (115 $\mu \mathrm{L}$ ) was added in each well (freshly prepared by mixing 45 $\mu \mathrm{L}$ phenol reagent with $70 \mu \mathrm{L}$ of alkali reagent) and incubation is continued for another $10 \mathrm{~min}$. Absorbance (after-read) was read. The percentage enzyme inhibition was calculated by the following formula:

$$
\begin{gathered}
\text { Inhibition }(\%)=100-[(\text { Absorbance of sample } / \\
\text { Absorbance of control }) \times 100]
\end{gathered}
$$

$I C_{50}$ values (concentration at which $50 \%$ enzyme catalyzed reaction occurs) of active compounds were found by measuring activities at lower concentrations $(0.5$, $0.25,0.125,0.06,0.03 \mathrm{mM}$ ) of test compounds and data was computed by using EZ-Fit Enzyme software, Perrella Scientific Inc. Amherst USA.

\section{Molecular Docking studies}

The synthesized series of ligands and their metal complexes were docked inside acetylcholinesterase enzymes to determine their putative binding mode. Auto Dock v4.2 and MGL Tools v1.5.6 [19] was used to carry out docking as previously reported [20]. The protein structures of acetylcholinesterase i.e. PDB ID 4BDT was downloaded from RCSB protein data bank. Preliminary steps of protein preparation such as removal of co-crystallized solvents; addition of hydrogen atoms and assigning appropriate charges to the residues was performed. The ligand molecules and their respective metal complexes were sketched and 3D optimized using Marvin Sketch.

The docking protocol was first reassured by redocking the reference ligand huprine inside acetylcholinesterase. After successfully reproducing similar binding pose for huprine, docking of ligands and their complexes was performed. Lamarckian genetic algorithm was used to generate different poses of the testligands and complexes. The top ranking poses with respect to their binding affinity were then selected and carefully visualized in Discovery Studio Visualizer v4.0 and the binding pose was then selected [21].

\section{Results and discussions}

The analytical data of enaminone ligands and complexes are given in the previous section. Ligands are soluble in ethanol, methanol, dichloromethane and chloroform. Complexes are soluble in DMSO and DMF. Molar conductance of the complexes $(0.001 \mathrm{M})$ was determined in DMSO. The conductance values $\left(1-20 \mathrm{ohm}^{-}\right.$ ${ }^{1} \mathrm{~cm}^{2} \mathrm{~mol}^{-1}$ ) indicate that the complexes were nonelectrolyte in nature [22]. The $\mathrm{C}, \mathrm{H}$, and $\mathrm{N}$ analysis of enaminone ligands and their metal complexes were found in good agreement with the expected values. $\lambda_{\text {max }}(\mathrm{nm})$ of the complexes were determined by UV-Visible spectroscopy.

\section{FT-IR spectra}

In the infrared spectra of the ligands (AC-PCA and AC$B A)$, band at ( $3125 \mathrm{~cm}^{-1}$ and $\left.3132 \mathrm{~cm}^{-1}\right)$ respectively is due to $v(\mathrm{~N}-\mathrm{H})$ vibration. There are two strong bands at $\left(1655 \mathrm{~cm}^{-1}, 1593 \mathrm{~cm}^{-1}\right)$ and $\left(1548 \mathrm{~cm}^{-1}, 1561 \mathrm{~cm}^{-1}\right)$ are assignable to $v(C=0$, conjugated $)$ and $v(C=C)$, respectively. The IR spectra of the synthesized complexes exhibited that ligands (Ac-PCA and Ac-BA) coordinate in the neutral bidentate mode. Bands at $1605 \mathrm{~cm}^{-1}$ to 1645 $\mathrm{cm}^{-1}$ assigned to carbonyl group and that at $1541 \mathrm{~cm}^{-1}$ to $1570 \mathrm{~cm}^{-1}$ assigned to $\mathrm{C}=\mathrm{C}$. The presence of $v(\mathrm{NH})$ band at $3405-3450 \mathrm{~cm}^{-1}$ in the spectra of all the complexes suggested that the hydrogen atom is not removed and the (NH) group is involved in the coordination [23]. Moreover, new bands in the spectra of all metal complexes appeared in the low frequency regions at 443-463 $\mathrm{cm}^{-1}$ and $525-560$ $\mathrm{cm}^{-1}$ are assignable to $v(\mathrm{M}-\mathrm{N})$ and $v(\mathrm{M}-\mathrm{O})$ bonds, respectively [24].

\section{${ }^{1} H$ NMR spectra}

${ }^{1} \mathrm{H}-\mathrm{NMR}$ spectrum of synthesized compounds were recorded. The indication for connecting mode of ligand was also provided by the ${ }^{1} \mathrm{H}$-NMR spectrum of ligand along with the complex of $\mathrm{Cd}(\mathrm{II})$. ' $\mathrm{H}-\mathrm{NMR}$ of ligand (Ac-PCA) revealed the presence of a single proton at $12.71 \mathrm{ppm}$ due to the enamine $\mathrm{N}-\mathrm{H}$ group [25]. Aromatic protons were found as two dublets of triplet at $7.35 \mathrm{ppm}$ and $7.03 \mathrm{ppm}$. Moreover, methyl protons also show two singlets at 2.38 $\mathrm{ppm}$ and $2.18 \mathrm{ppm}$. These chemical shift values corresponded well with the proposed structure of the ligand. ${ }^{1} \mathrm{H}$ NMR of ligand (AC-BA) showed the presence of a single proton at $11.68 \mathrm{ppm}$ due to the enamine $\mathrm{N}-\mathrm{H}$ group. Aromatic protons merged with each other and emerged as multillplet in the range $7.40-7.25 \mathrm{ppm}$. The $-\mathrm{CH}_{2}$ group exhibits a doublet at $4.52 \mathrm{ppm}$. Moreover, methyl protons also show two singlets at $2.32 \mathrm{ppm}$ and $2.17 \mathrm{ppm}$. These chemical shift values corresponded well with the suggested structure of the ligand.

In the complex of $C d(I I)$, the slight shifting of chemical shift values of all protons confirms the formation of metalligand bonds. In addition, the presence of NH signal in the spectrum of complex indicated that $\mathrm{N}$ forms coordinate covalent bond with metal ion while its hydrogen remains intact. So enaminone ligand (AC-PCA) acts as a bidentate ligand by bonding through nitrogen and oxygen [11]. These observations are in consistent with the interpretation of IR spectra.

\section{${ }^{13} \mathrm{C}$ NMR Spectra}

The number of signals in ${ }^{13} \mathrm{C}$ NMR spectrum supportwell with the proposed structure of ligands along with the number of carbon atoms which are chemically different. ${ }^{13} \mathrm{C}$ NMR of ligand (AC-PCA) showed peaks at 194.97, 157.74, 137.05, 131.73, 129.37, 126.51, 104.93, 28.67, 18.15 ppm. Similarly, ${ }^{13} \mathrm{C}$ NMR of ligand (AC-BA) showed peaks at 193.60, 161.19, 137.50, 128.93, 127.66, 126.77, 102.61, $47.69,28.66,16.68 \mathrm{ppm}$. These signals are in consistent with the proposed structures.

\section{Mass spectrum}

FAB-MS of ligands were recorded in which AC-PCA showed peak at 244.1 as $[\mathrm{M}+\mathrm{H}]^{+}$while in the spectrum of Ac-BA signal was observed at 224.1as $[\mathrm{M}+\mathrm{H}]^{+}$. 


\section{Thermogravimetry (TGA)}

TGA of metal complexes were done to check their stabilities and decomposition pattern on heating. TGA data of the complexes are given in (table 1). The correlations between the weight losses and decomposition steps of the complexes are discussed in terms of the suggested formulae of the complexes.

The (Ac-PCA)Cu(II) complex with molecular formula $\left[\mathrm{C}_{11} \mathrm{H}_{11} \mathrm{Cl} \mathrm{CuNO}\right.$ ] displayed three stages of mass loss between $\left(180-550^{\circ} \mathrm{C}\right)$. The first stage is at $180-220^{\circ} \mathrm{C}$ and showed a mass loss of $19 \%$, resulted in the loss of two chlorides (calc., $18.7 \%$ ). The second step occurs at 220$280^{\circ} \mathrm{C}$, with a mass loss of $60 \%$, leading to the loss of $\mathrm{C}_{11} \mathrm{H}_{11} \mathrm{Cl}_{2} \mathrm{~N}$ (calc., $60.23 \%$ ). The last stage of decomposition takes place between $280-550{ }^{\circ} \mathrm{C}$, with a mass loss of $21 \%$, leading to the loss of $\mathrm{CuO}$ (calc., $21.08 \%$ ).

The (Ac-PCA) $\mathrm{Cd}$ (II) complex with molecular formula $\left[\mathrm{C}_{22} \mathrm{H}_{22} \mathrm{Cl}_{6} \mathrm{CdN}_{2} \mathrm{O}_{2}\right]$ exhibited three steps of mass loss between $90-530^{\circ} \mathrm{C}$. The first step occurs at $90-120^{\circ} \mathrm{C}$, with a mass loss of $5 \%$, leading to the loss of one chloride (calc., $5.28 \%$ ). The second step of decomposition occurs at 120 $250^{\circ} \mathrm{C}$ and is due to the loss of five chlorides with a mass loss $26.0 \%$ (calc., 26.40\%). The third step of decomposition takes place between $250-530^{\circ} \mathrm{C}$, with a mass loss of $69 \%$, leading to the loss of $\mathrm{C}_{22} \mathrm{H}_{22} \mathrm{CdN}_{2} \mathrm{O}_{2}$ (calc., $68.20 \%$ ).

The (Ac-BA) Cu(II) complex with molecular formula $\left[\mathrm{C}_{11} \mathrm{H}_{2} \mathrm{ClCuNO}_{5}\right.$ ] displayed four steps of mass loss between $50-50^{\circ} \mathrm{C}$. The first step is between $50-190^{\circ} \mathrm{C}$, and is due to a mass loss of $27 \%$, leading to the loss of two acetates (calc., $28.8 \%$ ). The second step takes place at $190-275^{\circ} \mathrm{C}$, with a mass loss of $29 \%$, leading to the loss of $\mathrm{C}_{5} \mathrm{H}_{5} \mathrm{CIN}$ (calc., 28.6\%). The third step of decomposition takes place at $275-345^{\circ} \mathrm{C}$, with a mass loss of $23 \%$, leading to the loss of $\mathrm{C}_{7} \mathrm{H}_{7}$ (calc., $22.4 \%$ ). The fourth step of decomposition take place between $345-550^{\circ} \mathrm{C}$, with a mass loss of $20 \%$, leading to the loss of $\mathrm{CuO}$ (calc., $19.6 \%$ ).

The (Ac-BA) Co(II) complex with molecular formula $\left[\mathrm{C}_{2} \mathrm{H}_{3} \mathrm{Cl}_{2} \mathrm{CON}_{2} \mathrm{O}\right.$ ] displayed four steps of mass loss between $180-450^{\circ} \mathrm{C}$. The first step is at $50-170^{\circ} \mathrm{C}$, and showed a mass loss of $18 \%$, leading to the loss of two acetates (calc., $18.9 \%$ ). The second step takes place at $170-260^{\circ} \mathrm{C}$, with a mass loss of $12 \%$, leading to the loss of two chlorides (calc., $11.3 \%$ ). The third step of decomposition takes place between $260-325^{\circ} \mathrm{C}$, with a

mass loss of $31 \%$, leading to the loss of $\mathrm{C}_{12} \mathrm{H}_{12} \mathrm{NO}$ (calc., $30.1 \%$ ). The fourth step of decomposition take place between the temperature range $325-450^{\circ} \mathrm{C}$, with a mass loss of $39 \%$, leading to the loss of $\mathrm{C}_{12} \mathrm{H}_{14} \mathrm{CONO}$ (calc., 39.5 $\%)$. The decomposition patterns of the newly synthesized complexes are in consistent with their suggested structures.

\section{UV-Vis data and Magnetic moment}

The electronic absorption spectrum of the complexes in DMSO was recorded in UV-visible region. It was noted that all complexes show characteristic metal'!ligand charge transfer absorption bands between 265-385 nm, which are due to metal $(\mathrm{d} \pi-\mathrm{M})$ to ligand $\left(\mathrm{d} \pi^{*}\right)$ charge transfer [26]. The electronic spectrum of (AC-PCA)Cu(II) and (Ac-BA) Cu(II) complexes exhibited absorption bands at $745 \mathrm{~nm}$ and $730 \mathrm{~nm}$ respectively that can be due to the ${ }^{2} \mathrm{~T}_{2}$ '! ${ }^{2} \mathrm{E}$ transition of a tetrahedral geometry. (ACPCA)Cu(II) and (AC-BA)Cu(II) complexes showed magnetic moment value (2.15 B.M.) and (2.10 B.M.) respectively, that also support 4-coordinate tetrahedral geometry [27]. The (Ac-BA) $\mathrm{Co}$ (II) complex showed a band of moderate intensity at $550 \mathrm{~nm}$ which is allocated to the transition ${ }^{4} \mathrm{~T}_{10}(\mathrm{~F}){ }^{\prime} !{ }^{4} \mathrm{~T}_{\mathrm{g}}(\mathrm{P})(\mathrm{i})$. The magnetic moment value of $(\mathrm{AC}-\mathrm{BA}){ }_{2} \mathrm{Co}(\mathrm{II})^{\mathrm{g}}$ complex was found to be (4.19B.M.) which also reveals that ithas typically octahedral geometry [26]. The (Ac-PCA) ${ }_{2} \mathrm{Cd}(\mathrm{II})$ complex did notshow any $d$ - $d$ transition and its spectrum showed only charge transfer band. As expected it is diamagnetic; the complex is suggested to be octahedral geometry based on analytical, IR and conductance data [28, 29].

\section{Biological activity \\ Anti-AChE activity}

Compound (AC-BA)Cu(II) exhibited significant AChE inhibition of about $80 \%$ at $0.5 \mathrm{mM}$ with $\mathrm{IC}_{50}$ value of 22.43 $\pm 0.12 \mu \mathrm{M}$ as compared to the less active compound (AcPCA)Cu(II) which had IC value of $186.82 \pm 0.14 \mu \mathrm{M}$. Ligands and $\mathrm{Co}(\mathrm{II})$ or $\mathrm{Cd}^{59}(\mathrm{II})$ complexes did not show enzyme inhibition. There seems an involvement of $\mathrm{Cu}(\mathrm{II})$ complex in the inhibition of the enzyme (table 2).

\section{Anti-urease activity}

Table 1

THERMOGRAVIMETRIC ANALYSIS DATA FOR THE COMPLEXES

\begin{tabular}{|c|c|c|c|}
\hline Sample code & $\begin{array}{l}\text { Temperature range } \\
\left({ }^{\circ} \mathrm{C}\right)\end{array}$ & $\begin{array}{l}\text { (\%) Weight loss } \\
\text { calc/found }\end{array}$ & Assignments \\
\hline \multirow{3}{*}{ (Ac-PCA) $\mathrm{Cu}$ (II) } & $180-220$ & $18.70(19)$ & Two chlorides \\
\hline & $220-280$ & $60.23(60)$ & $\mathrm{C}_{11} \mathrm{H}_{11} \mathrm{Cl}_{2} \mathrm{~N}$ \\
\hline & $280-550$ & $21.08(21)$ & $\mathrm{CuO}$ \\
\hline \multirow{3}{*}{$(\mathrm{Ac}-\mathrm{PCA})_{2} \mathrm{Cd}(\mathrm{II})$} & $90-120$ & $5.28(5)$ & $\mathrm{Cl}$ \\
\hline & $120-250$ & $26.40(26)$ & Five chlorides \\
\hline & $250-530$ & $68.20(69)$ & $\mathrm{C}_{22} \mathrm{H}_{22} \mathrm{CdN}_{2} \mathrm{O}_{2}$ \\
\hline \multirow{4}{*}{$(\mathrm{Ac}-\mathrm{BA}) \mathrm{Cu}$ (II) } & $50-190$ & $28.8(27)$ & Two acetate groups \\
\hline & $190-275$ & $28.6(29)$ & $\begin{array}{l}\text { Partial decomposition of the } \\
\text { complex }\left(\mathrm{C}_{3} \mathrm{H}_{5} \mathrm{CIN}\right)\end{array}$ \\
\hline & $275-345$ & $22.4(23)$ & $\begin{array}{l}\text { Complete decomposition of the } \\
\text { complex } \\
\left(\mathrm{C}_{7} \mathrm{H}_{7}\right)\end{array}$ \\
\hline & $345-550$ & $19.6(20)$ & $\mathrm{CuO}$ \\
\hline \multirow{4}{*}{$(\mathrm{Ac}-\mathrm{BA})_{2} \mathrm{Co}$} & $50-170$ & $18.9(18)$ & Two acetate groups \\
\hline & $170-260$ & $11.3(12)$ & Two chlorides \\
\hline & $260-325$ & $30.1(31)$ & $\begin{array}{l}\text { Partial decomposition of the } \\
\text { complex }\left(\mathrm{C}_{12} \mathrm{H}_{14} \mathrm{NO}\right)\end{array}$ \\
\hline & $325-450$ & $39.5(39)$ & $\begin{array}{c}\text { Complete decomposition of the } \\
\text { complex } \\
\left(\mathrm{C}_{12} \mathrm{H}_{14} \mathrm{CoNO}\right)\end{array}$ \\
\hline
\end{tabular}


Table 2

ACHE AND UREASE INHIBITION STUDIES OF LIGANDS AND THEIR COMPLEXES (mean \pm s.e.m., $\mathrm{n}=3$ )

\begin{tabular}{|c|c|c|c|c|c|}
\hline \multirow[b]{2}{*}{$\begin{array}{l}\text { Sr. } \\
\text { No. }\end{array}$} & \multirow[b]{2}{*}{ Compound } & \multicolumn{2}{|c|}{ AChE } & \multicolumn{2}{|c|}{ Urease } \\
\hline & & $\begin{array}{c}\text { Inhibition (\%) } \\
\text { at } 0.5 \mathrm{mM}\end{array}$ & $\mathrm{IC}_{50}(\mu \mathrm{M})$ & $\begin{array}{c}\text { Inhibition (\%) at } \\
0.25 \mathrm{mM}\end{array}$ & $\mathrm{IC}_{50}(\mu \mathrm{M})$ \\
\hline 1. & Ac-PCA & $3.96 \pm 0.15$ & - & $41.27 \pm 0.16$ & - \\
\hline 2. & $(\mathrm{Ac}-\mathrm{PCA})_{2} \mathrm{Cd}(\mathrm{II})$ & $8.35 \pm 0.13$ & - & $49.25 \pm 0.18$ & - \\
\hline 3. & (Ac-PCA)Cu(II) & $81.64 \pm 0.18$ & $186.82=0.14$ & $65.32 \pm 0.19$ & $133.81 \pm 0.16$ \\
\hline 4. & $A c-B A$ & $24.25 \pm 0.13$ & - & $58.71 \pm 0.18$ & $172.46 \pm 0.15$ \\
\hline 5 & $(\mathrm{Ac}-\mathrm{BA}) \mathrm{Cu}(\mathrm{II})$ & $79.87 \pm 0.19$ & $22.43 \pm 0.12$ & $63.95 \pm 0.19$ & $152.71 \pm 0.16$ \\
\hline 6. & $(\mathrm{Ac}-\mathrm{BA})_{2} \mathrm{Co}(\mathrm{II})$ & $31.43 \pm 0.23$ & - & $91.24 \pm 0.17$ & $26.54 \pm 0.13$ \\
\hline 7. & Thiourea & - & - & $98.21 \pm 0.18$ & $21.25 \pm 0.15$ \\
\hline 8. & Eserine & $91.27 \pm 1.17$ & $0.04=0.0001$ & - & - \\
\hline
\end{tabular}

Table 3

BINDING FREE ENERGY OF LIGANDS AND METAL COMPLEXES INSIDE ACHE ENZYME

\begin{tabular}{|c|c|c|}
\hline \multirow{2}{*}{ Sr. No. } & \multirow{2}{*}{ Code } & AChE \\
\cline { 3 - 3 } & & $\begin{array}{c}\text { Binding Free Energy } \\
\left(\mathrm{Kcal} \mathrm{mol}^{-1}\right)\end{array}$ \\
\hline 1. & Ac-PCA & -6.55 \\
\hline 2. & $(\mathrm{Ac}-\mathrm{PCA})_{2} \mathrm{Cd}(\mathrm{II})$ & +3.82 \\
\hline 3. & $(\mathrm{Ac}-\mathrm{PCA}) \mathrm{Cu}(\mathrm{II})$ & -7.03 \\
\hline 4. & $\mathrm{Ac}-\mathrm{BA}$ & -7.24 \\
\hline 5. & $(\mathrm{Ac}-\mathrm{BA}) \mathrm{Cu}(\mathrm{II})$ & -8.52 \\
\hline 6. & $(\mathrm{Ac}-\mathrm{BA})_{2} \mathrm{C}$ (II) & +9.46 \\
\hline
\end{tabular}

complex several non-bonding interactions were found with residues of esteric site of binding pocket. The metal complex does not form any significant interaction with any residue. However, itmay be responsible for maintaining the pose in its low est energy state inside the active pocket and thus yielding highest binding affinity. (Fig. 1) shows the plausible binding poses of $3(\mathrm{Ac}-\mathrm{PCA}) \mathrm{Cu}(\mathrm{II})(\mathrm{a})$ and 3(Ac-BA)Cu(II) complex (b).

\section{Conclusions}

The current studies provide a simple protocol for the manufacture of enaminones and their metal complexes. The synthesized compounds were investigated for antiureas as well as anti-AChE activity. The complex (Ac-

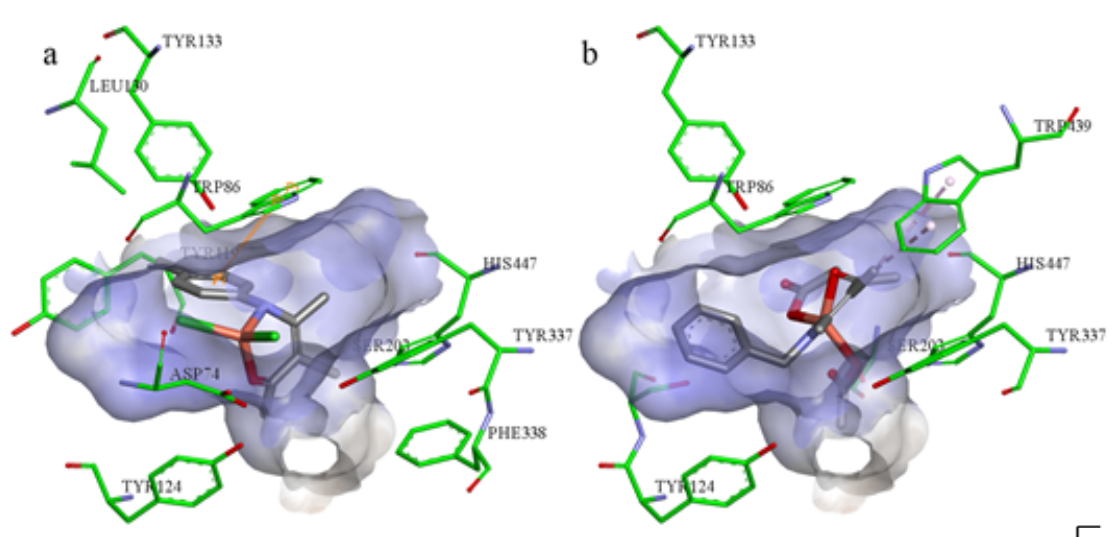

Fig. 1. Putative Binding Pose of 3(AcPCA)Cu(II) (a) and 3(Ac-BA)Cu(II) (b); Metal complex inside Human AChE Binding Pocket

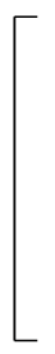

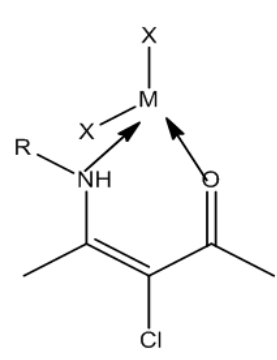<smiles>[CH]=C</smiles>

Where $\mathrm{M}=\mathrm{Cu}(\mathrm{II})$ $\mathrm{X}=\mathrm{Cl} / \mathrm{CH} 3 \mathrm{COO}$ $\mathrm{R}=-\mathrm{Ph}-\mathrm{Cl} / \mathrm{Ph}-\mathrm{CH} 2$

\section{Molecular docking studies}

Molecular docking was carried out with an aim to determine the most plausible binding poses of the complexes inside the active pocket of acetylcholinesterase. The $\mathrm{Cu}(\mathrm{II})$ complexes of ligands AC-PCA and AC-BA were found to have higher binding affinity as compared to rest of the synthesized complexes (table 3). The highestbinding affinity of $-8.52 \mathrm{Kcal} \mathrm{mol}^{-1}$ was observed for (AC-BA)Cu(II) complex while in case of (AC-PCA)Cu(II) complex, the observed binding affinity was $-7.03 \mathrm{Kcal}$ $\mathrm{mol}^{-1}$. Cu(II) complexes of Ac-BA and Ac-PCA were found to reside inside the esteric and anionic binding site of the active site. Chlorophenyl ring of (AC-PCA)Cu(II) complex forms $\pi-\pi$ stacking -interaction with residue Trp-86 of the anionic binding pocket while in case of (Ac-BA)Cu(II)

Fig. 2. Proposed structure of 4-coordinated enaminone complexes

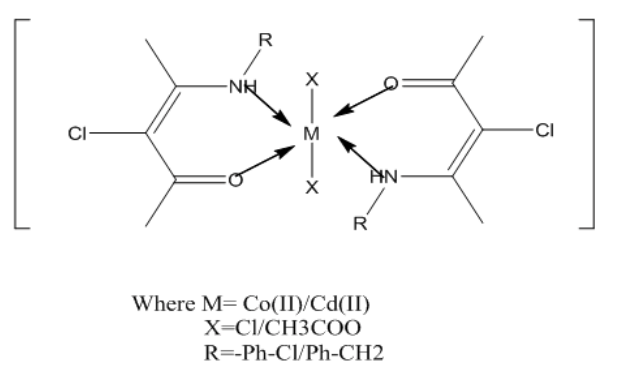

Fig. 3. Proposed structure of 6-coordinated enaminone complexes 
$\mathrm{BA}) \mathrm{Cu}(\mathrm{II})$ exhibited good anti-AChE activity with $\mathrm{IC}_{50}$ value $22.43 \pm 0.12 \mu \mathrm{M}$ and (AC-BA) ${ }_{2}$ (II) potent anti-urease activities with $I C_{50}$ value $26.54 \pm 0.13 \mu \mathrm{M}$. Molecular docking studies showed $\mathrm{Cu}(\mathrm{II})$ complexes of ligands ACPCA and AC-BA were found to have higher binding affinity as compared to rest of the synthesized complexes.

Spectroscopic techniques were well supported to our designed structures (fig. $2 \& 3$ ).

Acknowledgement: The authors are grateful to Higher Education Commission (HEC), Govt. of Pakistan for access to Scientific Instrumentation and Institute of Chemistry, University of the Punjab, Lahore-54590, Pakistan, for providing laboratory facilities.

\section{References}

1. EMAN, A.E., KHALED, H.H., SAFAA, K.H.K., NABIL, S.Y., Aust.J .Basic Appl.Sci., 2, 2008, p. 210

2. FURST, A., HARO, R.A., Prog.Exp.Tumor Res., 12, 1969, p. 102

3. GHANDHI, M., JAMEA, A.H., Tetrahedron Lett., 52, 2011, p. 4005

4. MANSOUR, S.A., MOSTAFA, M.G., MAUREEN, H., ALBENA, T., DNKOVAL, K., ABDELAATY, A.S., Biomed.Res., India, 26, 2015, p. 7 5.CHEN, X., SHE, J., SHANG, Z.C., WU, J., ZHANG, P.Z., Synthetic Commun., 39, 2009, p. 947

6. ELASSAR, A.Z., EL-KHAIR, A., Tetrahedron, 59, 2003, p. 8463

7. CONCETTA, M., J.Brazil.Chem.Soc., 14, 2003, p. 945

8.KIM, J., HWANG, J.W., KIM, Y., LEE, M.H., HAN, Y., DO, Y., J.Organomet.Chem., 620, 2001, p. 1

9.LI, X.F., DAI, K., YE, W.P., PAN, L., LI, Y.S., Organometallics, 23, 2004, p. 1223

10. MAHMUD, T., REHMAN, R., GULZAR, A., KHALID, A., ANWAR, J., SHAFIQUE, U., SALMAN, M., Arab.J.Chem., 3, 2010, p. 219

11. JERAGH, B., ABDEL-ZAHER, A.E., Chem.Sci.Trans., 4, 2015, p. 113 12. SHI, Y.C., SHEN, W.B., YANG, H.M., SONG, H.B., HU, X.Y., Polyhedron, 23, 2004, p. 749
13. FILYAKOVA, V.I., CHIZHOV, D.L., KHMARA, E.F., CHARUSHIN, V.N., Russ.J. Gen.Chem., 80, 2010, p. 190

14. STABNIKOV, P.A., ZHARKOVA, G.L., BAIDINA, I.A., TKACHEV, S.V., KRISYUNK, V.V., IGUMENOV, K., Polyhedron, 26, 2007, p. 4445

15. SCHLEAEFER, J., GRAF, D., FORNALCZYK, G., METTENBOERGER, A., MATHUR, S., Inorg.Chem., 55, 2016, p. 5422

16. MARTIN, D.F., JANUSONIS, G.A., MARTIN, B.B., J.Am.Chem.Soc., 8, 1961, p. 73

17. ELLMAN, G., COURTNEY, K.D., ANDRES, V., FEATHERSTONE, R.M., Biochem.Pharmacol., 7, 1961, p. 88

18. WEATHERBURN, M.W., Anal.Chem., 39, 1967, p. 971

19. MORRIS, G.M., J.Comput.Chem., 30, 2009, p. 2785

20. MURTAZA, S., ABBAS, A., IFTIKHAR, K., SHAMIM, S., AKHTAR, S.M., RAZZAQ, Z., NASEEM, K., ELGORBAN, M.A., Med.Chem.Res., 25, 2016, p. 2860

21. *** Discovery Studio Visualizer, 2005

22. GEARY, W.J ., Coord.Chem.Rev., 7, 1971, p. 81

23. SOUAD, A.O., HANAN, A.M., HISHAM, A.A.Y., TAGHRID, S.H., ABDALLAH, A., MOHAMED, M.A., ASHRAF, S.H., J.Serb.Chem.Soc., 79, 2014, p. 953

24. PANSURIYA, P.B., PATEL, M.N., Appl.Organomet.Chem., 21, 2007, p. 926

25. SHI, Y.C., SUI, C.X., SONG, H.B., JIAN, P.M., J.Coord.Chem., 58, 2005, p. 363

26. YANG, L.J., LIU, Q.L., WANG, M.X., GU, L.S., LUO, Y.H., SUN, B.W., Spectrochim. Acta A, 166, 2016, p. 1

27. HERGOLD-BRUNDIC, A., KAITNER, B., KAMENAR, B., LEOVAC, V.M., Inorg.Chim.Acta, 188, 1991, p. 151

28. MOHAMED, G.G., ZAYED, M.A., EL-GAMEL, N.E.A., Spectrochim. Acta A, 58, 2002, p. 3167

29. OMAR, M.M., MOHAMED, G.G., Spectrochim. Acta A, 61, 2005, p. 929

Manuscript received: 30.03 .3018 